\title{
Mit kezdjünk Európával?
}

\section{A hazai politikai elitek mintakövetési és mintaformálási stratégiája}

\author{
CSIZMADIA ERVIN ${ }^{1}$
}

\begin{abstract}
ABSZTRAKT
Az elmúlt évtizedekben a hazai elitkutatók az elitek szerveződésének és viselkedésének szinte minden szegmensét feltárták, de meglepöen keveset foglalkoztak a külső erôtérnek (Európának, a Nyugatnak) az elitek gondolkodására és cselekvésére gyakorolt hatásával. Az elitek ilyen szempontú megközelítésének hiánya már csak azért is feltünő, mert az elmúlt harminc évben két esetben is látványosan megváltozott az elitek Európa-orientációja (z 1980-as években és az 1990-es évek másodikm felétől). A tanulmány középpontjában e két Európa-kép bemutatása áll, amelyek közül az egyiket (s ezt képviseli a bal-és a liberális oldal) mintakövetőnek, a másikat (s ez jellemzi a kormányzó oldalt) mintaformáló jelzővel illethetjük. A dolgozat bemutatja mindkettô keletkezéstörténetét, illetve kapcsolódását makro- és mikropolitikai motívumokhoz. Ennek keretében a tanulmány kitér arra, miért volt adekvát az 1980-as években a mintakövetô álláspont megjelenése, s arra is, hogy az 1990-es évek közepén miért jelent meg a mintakövetö attitüd mellett, mintegy annak kihívójaként a mintaformáló Európa-attitűd a jobboldalon. De az elemzés nem csak az elmúlt harminc év folyamatainak dinamikus bemutatását vállalja magára, hanem azt is, hogy rámutasson: a tágabb magyar politikatörténetet is be kell kapcsolnunk, ha meg akarjuk érteni a nyugathoz való elit-viszony tekintetében az elmúlt évtizedek során bekövetkező változásokat. A magyar politikatörténetben mélyen benne rejlik az a réteg, amelyet az elmúlt évtizedben a Fidesz előhozott belóle. Ezzel a réteggel pedig akkor is számolnunk kell, ha azt netán taszítónak találjuk és elvetjük.
\end{abstract}

KULCSSZAVAK: elitek, külső minták, mintakövetés, mintaformálás, komplex politikatörténet

\section{ABSTRACT}

\section{How should we think about Europe? \\ The model adaptation and model formation strategy of the Hungarian political elite}

In the past decades, researchers in Hungary have looked at almost all segments of the behavior and organization of elites, nevertheless they have dealt surprisingly little with how external actors (Europe, the West) affect the actions and way of thinking of the elites. The lack of approaches from this perspective is so apparent because the European orientation of the elites has changed twice in the past thirty years. (In the 1980s and starting from the second half of the 1990s.) The

${ }^{1}$ MTA Politikatudományi Intézet (Senior researcher, haS Centre for Social Sciences institute for Political Science), tudományos főmunkatárs. e-mail:Csizmadia.Ervin@tk.mta.hu 


\section{KÖZELKÉP - Tanulmányok}

essay focuses on presenting two concepts of Europe, of which one is based on model adaptation (the opposition represents this approach) the other on model formation (which is characteristic of the governing parties). The essay shows the origins of both, as well as their connections to macro and micro political motifs. Within the frameworks of this, the study touches upon why the appearance of the model adaptation perspective was adequate in the 1980s as well as to why the model forming approach to Europe appeared on the right in the middle of the 1990s as its challenger. The analysis does more than just dynamically present the past thirty years, it also aims to show that we have to integrate Hungarian political history in a broader sense into our studies if we want to understand the changes that have occurred in the past decades concerning the relationship of the elites to the West. The stratum which Fidesz has brought to surface lays deep in Hungarian political history. We have to take this stratum into consideration even if we find this perhaps unattractive and we reject it.

KEYWORDS: Elites, external examples, model adaptation, model transformation, complex political history

\section{Bevezetés}

Az elmúlt évtizedekben a hazai elitkutatók az elitek szerveződésének és viselkedésének szinte minden szegmensét feltárták, de meglepően keveset foglalkoztak a külső erőtérnek (Európának, a Nyugatnak) az elitek gondolkodására és cselekvésére gyakorolt hatásával. Az elitek ilyen szempontú megközelítésének hiánya már csak azért is feltűnő, mert az elmúlt harminc évben két esetben is nagyon látványosanmegváltozott az elitek Európa-orientációja, tehát volna miről elgondolkodunk. Az első az 1989-90-es rendszerváltás, a második pedigaz a rendszerváltás, amely az első Fidesz-kormányzással (1998-2002) kezdődik és 2010 utáni többszöri kétharmados kormányzással teljesedik ki. A két korszak nagyon különböző karakterű, de közös jellemzőjük, hogy mindkettőben megváltozik az addig uralkodónak tekinthető Nyugat-percepció. Míg a 80-as évek közepéig az eliten belül nincs látványos jele a nyugatosságnak, addig ekkortól egy nagyon egyértelmű Európa-orientáció jelenik meg, amelyet mintakövetőnek nevezek majd. Ez a mintakövető orientáció azonban már az 1990-es évek közepétől-második felétől kihívót kap, hogy aztán ez a kihívó 2010 után elforduljon a mintakövető stratégiától és egy új Európa-felfogás nevében lépjen fel. Ezt az új attitűdöt hívom mintaformálónak.

Ez a kategorizálás, mint kiindulópont önmagában is indoklásra szorul. A mai Magyarországról író nemzetközi és hazai (nem is elsősorban elit-) kutatók szinte kivétel nélkül arról írnak, hogy a mai kormány eltávolodott a liberális demokráciától(Enyedi - Krekó, 2018, Wilkin 2018, Krastev 2018), sőt itt már nem is eltávolodásról, hanem Európa-ellenességről beszélhetünk.Ehhez képest az én állításom az, hogy az Európa versus Európa-ellenesség dichotómia nem pontosan fejezi ki a mai helyzetet. A változás ugyanis nem az Európa-Európa-ellenesség irányban történt, hanem 


\section{KÖZELKÉP - Tanulmányok}

az európaiságon belül: a mintakövető európaiság mellett megjelent és kormányzati szintre emelkedett egy mintaformáló szemléletmód.

Dolgozatom középpontjában e két kategória áll. De, mint ahogy a mintaformáló gondolkodás megjelenése sem volt előre kiszámítható és szükségszerü, úgy a mintakövető megjelenése sem volt az 1980-as évek második felében. Mindkettőt objektív és szubjektív körülmények formálták ki - elemezni is fogom őket. Az elemzésben csak Magyarországra koncentrálok, amelyet egyedi példának tekintek.Az egyedi példák tanulmányozását mindig is fontosnak tartottam, az Orbán-kormány idején pedig hatványozottan fontosnak. Az ugyanis a véleményem, hogy a többszöri kétharmados Orbán-rendszert nem érthetjük meg egy általános, mondjuk régiócentrikus demokráciaelmélet felől. Ezért a dolgozatot érdemes úgy olvasni, hogy az eleve lemond a közös és általánosítható tanulságok kereséséről annak érdekében, hogy egyedi tanulságokra jusson.

A dolgozat első részében néhány alapfogalomról, illetve ezeknek a tanulmányban történő alkalmazásáról lesz szó. A második részben a mintakövető, a harmadikban a mintaformáló elitstratégiák jellegzetességeit veszem számba. A negyedik részben pedig magyarázatokat kívánok adni a változásokra.

\section{Irodalom, alapfogalmak és tájékozódási irányok}

\section{A KÜLSŐ MINTA ÉS A HOZZÁ VALÓ VISZONY INTERPRETÁLÁSÁNAK NÉHÁNY PÉLDÁJA}

Ahhoz, hogy erről az Európával kapcsolatos két elit-magatartásról (a mintakövetésről és a mintaformálásról) mind többet megtudjunk, először az alapfogalmakat, elsőként is a minta fogalmát kell tisztáznunk. A minta egy olyan országot vagy országcsoportot jelent, amely valamiért követendő vagy semlegesebben viszonyítási pont más országok elitjei számára. A mintához kétféleképp lehet viszonyulni. Az egyik - s ez a történelmileg jóval ismertebb - a mintakövetés, ami azt jelenti, hogyha az eliteknek alkalmuk nyílik rá,igyekeznek országukat közelebb vinni ehhez a külső mintához. Ez leggyakrabban intézményi és jogi adaptációt jelent, de része a mentális alkalmazkodás is. A magyar elitek a történelem számos pontján találták szembe magukat a kihívással, hogy az országot fel kell zárkóztatniuk a mintának tekintett fejlettebb régióhoz. A másik elit-attitűd a mintaformálás. Vannak ugyanis elitek, amelyek nem tartják megfelelőnek a mintakövetést, s úgy vélekednek, hogy az országnak nem csak a passzív követés, hanem az aktív mintaformálás is feladata.

Az 1980-as években - főképpen a szociológiában és a történettudományban nagymértékben előtérbe került a mintakövetés kérdése. Két fontos mű fémjelzi ezt. A szociológiában Kulcsár Kálmán: A magyar szociológia történetszemlélete. Gondolatok a külső minta jelentőségéről (Kulcsár, 1984) című tanulmánya; a 


\section{KÖZELKÉP - Tanulmányok}

történettudományban Szűcs Jenő híres könyve:Vázlat Európa három régiójáról (Szűcs, 1984). Mindkét szerzőt az izgatja, hogy Magyarország mennyiben tér el Nyugat-Európától és melyek az eltérések okai. A politikatudomány ekkor még éppen első lépéseit teszi meg az önálló diszciplínává válás útján, így e tudományterület képviselői e témában ekkor még nem nyilvánulnak meg. Annál nagyobb aktivitás jellemzi viszont a „nemzetközi kapcsolatok” diszciplína művelőit. Ốk - mint majd látjuk - számos folyóiratban fogalmaznak majd meg gondolatokat az európai nyitással (főképpen mintakövetéssel) kapcsolatban.

A politológusok a témára a rendszerváltás idején találnak rá. Ágh Attila például az átmenet után nem sokkal ezt írja: „A magyar politikatörténet a belpolitika és a nemzetközi viszonyok találkozásánál (linkage politics) azt mutatja, hogy a belső politikai erőteret egy rendkívül nagy befolyású külső erőcentrum strukturálja. Nemcsak az állam a „túlsúlyos” tényező tehát a történelmi fejlődésben, hanem fokozott mértékben egy olyan külső erőcentrum is, amely gyakran, áttételek nélkül, közvetlenül — jogilag- alkotmányosan és erőszak-szervezetileg is - belső tényező egyszersmind" (Ágh 1992: 134). Úgy ítéli meg, hogy a történeti magyar fejlődésben (dualizmus, Horthy-korszak) folyamatosan szerepet játszik a külső minta és ez a szerep nem szűnik meg a rendszerváltás után sem: „A magyar politikai rendszernek az Európához való „strukturális kompatibilitásra” kell felkészülnie, s ennek egyik mozzanata a pártrendszer keserves átalakulása lesz a nyugateurópai modellnek megfelelően, talán a posztmodem társadalom markáns jegyei kivételével. A magyar pártoknak és pártpolitikusoknak tehát abban kell gondolkodniuk a kilencvenes években, hogy milyen nagy pártfrakciók vannak az Európa Parlamentben, s hova fognak a képviselőik leülni, ha az európai integráció folyamata behívja a magyar politikát is." (Ágh 1992: 135). Ágh tehát - bár nem használja a mintakövetés fogalmat - a Nyugathoz való mind szorosabb illeszkedést, adaptációt látja kívánatosnak és ugyanezt teszi angol nyelvű cikkeiben is (Ágh 2011). Egy évvel Ágh után Kiss Zsolt Péter és Derényi András - akik ugyan szociológusok - az „utánzás régiójáról” beszél (Kiss-Derényi 1993).

Az 1990-es évtizedben Magyarország még nem tagja az Európai Uniónak, ezért egy ideig még a 80-as évek nyugatos megközelítései a dominánsak, ám az 1990-es években egyre inkább előtérbe kerülnek a demokratikus intézményrendszer alkalmazkodásának kérdései (Stepan - Skach 1993, Greven 1995). A 2004-es EU-csatlakozás utáni tizenöt évben pedig már nem csak arról olvashatunk, hogy mit jelent a külső közeg a mi számunkra, hanem arról is, hogy a hagyományos külső - belső elkülönítés már nem érvényes, hiszen Magyarország számára már nem külső erőtér Európa. Másrészt pedig arról, hogy mit jelentünk mi az EU számára, azaz hogyan alkalmazkodik az EU a 2010 utáni, kétharmados kormányzati helyzethez. Bozóki András és Hegedűs Dániel például „kívülről korlátozott hibrid rezsimként” írja le az orbánizmust. A szerzők ugyan nem foglalkoznak a nyugatosság kérdésével, de írásukból nyilvánvaló: az orbáni hibrid rendszer szerintük nem csak nem demokrácia, de az európaiság követelményének sem felel meg. 


\section{KÖZELKÉP - Tanulmányok}

\section{SAJÁT ELIT-FOGALOM:}

\section{AZ ELIT MINT A KÜLSŐ-BELSŐ NEXUS VÁLTOZÁSÁNAK JELZŐJE}

Lássuk most már, melyek az általam alkalmazott megközelítés legfontosabb vonásai. 1.) Mind a késő Kádár-rendszerben, mind az 1990-es évek második felétől létezik egy speciális elitcsoport, amely (amellett, hogy természetesen a belpolitikai erőtér része maga is) a nemzetközi viszonyokat tanulmányozza, és ez alapján szerez befolyást magának. 2.) E külpolitikai orientációjú elit mindkét magyar rendszerváltás (az 1989-90-es jól ismert és a Fidesz által később, több lépcsőben végrehajtott) esetében kiemelt szerepet töltbe: az első esetben egy nyugatos ideológiát kínált fel a közönségnek, a másodikban pedig a mintakövetés kritikáját végzi el. 3.) E csoportok erejét és befolyását nem csupán gondolataik tartalma, hanem azok (különböző formákban történő) intézményesítése adja. 4.) Az Európa témájával foglalkozó elitcsoportok közül mindkét korszakban kiemelhető egy-egy, amely különösen sokat tesz a maga által helyesnek gondolt európaiság előmozdításáért.

(A külső környezetre való elit-orientálódás). Egy a Kádár-rendszerrel kapcsolatos korábbi vizsgálatomban - a hatalom felső körei mellett - négy elitcsoportot találtam, amelyek azonosítható módon, a régi hatalmi elittől eltérő módon definiálták Nyugat-Európát. Ezek a csoportok: a pártértelmiség, a külpolitikai elit, a közgazdász-elit és az ellenzéki elit (Csizmadia 2001). Ezek az elitek külön-külön és együttesen is nagy hatással voltak egyrészt a régi külvilág-felfogás változására, másrészt magára a belpolitikai helyzetre is. ${ }^{2} \mathrm{~A}$ rendszerváltás után pedig azt találtam, hogy ez a több elit által kiformált, de a legerőteljesebben a demokratikus ellenzék által hordozott Európa-kép megteremti a maga riválisát a Fidesz képében. A Fideszmegalakulásától kezdve külsőkörnyezet-orientált párt, de önálló, a többi elittől megkülönböztethető nézetei a témában csak fokozatosan alakulnak ki.

(A rendszerváltások és a külpolitika-orientált elit szerveződésének összefüggései). A külpolitikai orientációjú eliteknek kiemelt szerepük van rendszerváltások előidézésében. A késő Kádár-kor elitjeit erre kívülről is ösztönzik a nyugati országok vezető körei, s ez a külső megerősítés szétterjeszti a nyugati mintát és segít a mintakövető elitek felnövekedésében. A második korszakban, az 1990-es évek közepén, majd pedig az MSZP-SZDSZ kormányzás (2002-2010) végénez a mintakövető nyugatosság jelenti a „status quot”, de vele szemben ekkorra már egy masszív jobboldali Európa-felfogás áll.

(A külső-belső nexus újszerü vizsgálatának intézményesítése). Fontos kiemelni, hogy a két különböző Európa-felfogást képviselő elitek nem csak más és más korszakban alakítják ki a maguk Európával kapcsolatos felfogását, hanem nézeteik

${ }^{2} \mathrm{Az}$ „együttes hatás” azt jelenti, hogy az elitcsoportok egy úgynevezett „diszkurzív diktatúrát” hoztak létre, amelyben az általuk fontosnak tartott témák is bekerültek a nyilvános disputák témái közé. Lásd: Csizmadia 2001. 


\section{KÖZELKÉP - Tanulmányok}

kifejtésére és terjesztésére nagyon másfajta reprezentatív közegeik vannak. Az 1980as években megszerveződő mintakövető elit döntően intellektuális oldalról érkezik, és folyóiratokat használ nézetei népszerűsítésére. Említett empirikus kutatásomban öt folyóirat (Társadalmi Szemle, Külpolitika, Közgazdasági Szemle, Külgazdaság, Beszélő)Európával kapcsolatos írásait olvastam át.Noha amegnevezett folyóiratoknak korántsem minden írása foglalkozott Európával, s amelyek ezzel foglalkoztak, azok mondanivalója sem vágott mindig egybe, de e folyóiratok hasábjain egyértelműen kimutatható egy nyugatos fordulat 1982 és 1988 között. A korai pártprogramoknak (Csizmadia 2001, Kovács - Tóth 1992) volt mire ráépülniük.

Amilyen gazdagon dokumentálható a mintakövető nyugatosság folyóiratokban és pártprogramokban, olyan nehézséget okoz a későbbi rivális, a mintaformáló európaiság azonosítása. Ennek oka az, hogy a mintaformáló gondolatiság kifejtése nem történik meg folyóiratokban, hanem rögtön pártprogramokban, azaz kimarad az intellektuális alapozás és a mintakövetés kritikájapolitikai manifesztumokban jelenik meg. Később, amikor már a pártprogramok is ritkulnak a Fidesz eszköztárában, az Európával kapcsolatos gondolkodás szinte kizárólag Orbán Viktor - intellektuálisnak szánt - beszédeiben kap helyet.

(Egy-egy elitcsoport kitüntetett szerepe). Ahogy jeleztem: az 1980-as években a nyugatos mintakövetést számos elitcsoport írásaiban megtaláljuk. Mivel az összes csoport Európa-képét részletesen kifejtettem másutt (Csizmadia 2001: 20-92), itt most csak arra koncentrálok, amelyik a leghatékonyabb és a legnyugatosabb volt. Ez a demokratikus ellenzék, illetve a belőle létrejövő SZDSZ. Csak akkor értjük meg, hogy a később kormányra kerülő Fidesz miért az SZDSZ-t tartja fő ellenfelének, ha tudjuk, hogy az SZDSZ mintakövető felfogása volt a Fidesz számára a legnagyobb ideológiai kihívás. ${ }^{3}$

\section{A DEMOKRATIKUS ELLENZÉK ÉS AZ SZDSZ KLASSZIKUS MINTAKÖVETŐ EURÓPAISÁGA}

Az 1980-as évek legkiemelkedőbb elitcsoportja a demokratikus ellenzék volt. Ez a nem túl nagy létszámú, ám annál eltökéltebb elit már az 1970-es évek közepén (tehát jóval a kettős függés korszakán innen) megszervezte önmagát és a magyar közéletben egyedülálló módon nyugatos orientációra váltott. Ehhez nagymértékben segítséget kapott Nyugat-Európából és az emberi jogok ideológiájából (Csizmadia 1995, Monográfia), valamint a kelet-közép-európai ellenzékektől, mindenekelőtt a lengyelektől (Mitrovits 2019). Ugyanakkor érdekes módon az ellenzék, bár a nyugati minta és a mintakövetés híve, egészen a rendszerváltásig nem fogalmaz meg teljes

${ }^{3}$ Az MSZP szervezeti kihívást jelentett, de ideológiait nem. Az SZDSZ pedig fordítva. A Fidesz nagy párttá akart válni, ehhez mind a két területen le kellett győznie a riválisokat. 


\section{KÖZELKÉP - Tanulmányok}

mintakövetéses koncepciót.1982 és 1988 között ez még egy nagyon visszafogott, egyben jól átgondolt mondanivaló. Az ellenzék reálpolitikát folytat, és nem akar, de - felkészültsége miatt - nem is tud Európa teljes valóságáról beszélni. Ami ezekben az években visszatérően előjön, az a szovjet-amerikai kapcsolatok értékelése. Az ellenzék óvatos: az első időkben szó nincs a Szovjetunió egyoldalú kritikájáról és az Egyesült Államok egyoldalú dicséretéről. Ezekben az években csak az biztos, hogy az ellenzék túl akar lépni 1977-1981 között követett stratégiáján. ${ }^{4}$ Fontos ellenzéki téma lesz a létező európai stabilitás. Vajon jó-e a fennálló stabilitás? Vannak-e, s ha igen, milyen geostratégiai érdekei a nyugat-európai országoknak Kelet-Közép-Európában? Abból, hogy a Nyugatnak nem érdeke a status quo felborítása, következik-e, hogy hozzájárulnak a status quo fenntartásához?

1981 után a demokratikus ellenzék elkezdi feszegetni az 1945 utáni világrend kereteit, azon belül Európa kettéosztottságának problémáját. Ezt pedig úgy teszi, hogy rámutat: a bipoláris világfelfogás a tömböket nem fellazítani, hanem megszilárdítani akarja, s azt állítja, hogy a blokkrendszer stabilizációja lehetséges (Csizmadia 1990: 234-235). Mások a „Jalta-Európa” értelmetlen fenntartásáról beszéltek. ${ }^{5}$ Vajon meddig fogadja még el a Nyugat a jaltai megosztottságot? A Beszélő és az ellenzék tehát a Jaruzelski-puccs utáni időszakban egyre erőteljesebben bírálta a „Helsinki formulát”, az enyhülés gyakorlatát, illetve az elrettentés kölcsönös egyensúlyára épülő nemzetközi rendet. A kormányokat és a politikusokat kényszerek foglyainak tekintette és velük szemben a civil társadalom vagy a „párhuzamos állam” koncepcióját támogatta.

Néhány évvel később ettől már eltérően alakul az ellenzék Nyugat-percepciója. 1985-ben főtitkár-váltás történik a Szovjetunióban, s egy évre rá ennek hatása Magyarországon is érződik: nagy reformpezsgés indul. ${ }^{6} \mathrm{E}$ pezsgés részének tekinthetjük a demokratikus ellenzék Társadalmi Szerződés című nagy dokumentumát, amely megint egy újabb Nyugat-képre épül. Ennek az új Nyugat-képnek a centrumában (nyilván felhasználva az előző évben megjelent reformprogramokat) a fejlett világgazdasághoz való felzárkózás állott. De ezen túlmenően a Társadalmi Szerződés az első ellenzéki szöveg, amely már nem csak egy statikus Nyugattal számol, hanem foglalkozik azokkal a változásokkal is, amelyek a 1970-es évek Nyugat-Európájában bekövetkeztek. E nyugati tapasztalatokból jön a tanulmány címe: a jóléti államok végén a nyugati politikusok és a nyugati társadalmak között modernizációs paktum jön létre a posztjóléti állam költségeinek megoszlásáról (Csizmadia 1995, Monográfia: 383-384).

${ }^{4} 1983$ elején vita indult a Beszélőben, hogy mi legyen az ellenzék szerepe a továbbiakban. A vitaindítót író Kis János azt szorgalmazta, hogy az ellenzék lépjen túl emberi jogi korszakán és forduljon nagypolitikai kérdések felé. Az ellenzék-vitáról lásd: Csizmadia 1990. I-II.

${ }^{5}$ Haraszti Miklós (1985): A helsinki giccs. Beszélő, 15. BÖK, II. kötet, 272.

6 1986-ban jelenik meg a reformközgazdászok tollából a Fordulat és reform című anyag és Bihari Mihály Reform és demokráciája. Az ismertebb folyóiratokban reformszellemű írások látnak napvilágot, de ezek többnyire belpolitikai tematikájúak. 


\section{KÖZELKÉP - Tanulmányok}

De miközben nagyon pontosan definiálja a magyar ellenzék a nyugati területeken bekövetkező változásokat, meghökkentő, hogy a Társadalmi Szerződés milyen visszafogott, amikor a Szovjetunió kilátásairól szól. A program szerzői megállapítják ugyan, hogy kimerültek a Szovjetunió olcsó természeti erőforrásai és válságba került a KGST rendszere, de azt megállapítják, hogy „a szovjet világrendszer felbomlásával számolni a belátható jövőben nem lehet." (Társadalmi szerződés 1987: 785) Ez már csak azért is meglepő visszalépés, mert korábban az ellenzék - mint láttuk - a bipoláris világrend fenntartása ellen érvel. 1987-ben azonban az ellenzék - legalábbis átmenetileg - megtorpan, vagy nagyon tudatosan befékezi magát. Ennek két oka van. Az egyik: a Szovjetunión belül 1987 tavaszára még nem dőlt el végérvényesen, hogy Gorbacsov milyen mértékben tudja keresztülvinni reformelképzeléseit. Nagyjából a Társadalmi Szerződés megjelenésével párhuzamosan zajlott le Moszkvában az SZKP ülése, amelyet a kortársak a „fordulat plénumának” neveztek. A másik: bár az ellenzék végig a társadalom, a „morajló embertömeg” strukturálására törekedett, s ennek szószólója kívánt lenni, törekvései csak korlátozott sikerrel jártak, nemigen tudta növelni társadalmi bázisát. Félő lehetett, hogy egy túlságosan radikális (netán „rendszerváltó”) program, egy túlságosan erőteljesen megfogalmazott csatlakozási szándék Európa nyugati feléhez, korai jelzés lett volna az erre teljesen felkészületlen magyar társadalomnak. Ebből a megfontolásból talán már jobban érthető, hogy a program azt mondja: Jaltát nem lehet felmondani, a cél: vitát nyitni az egyoldalú függés kiegyensúlyozásáról (Társadalmi szerződés 1987: 786).

S hogy mennyire vigyáznak az ellenzék képviselői a fogalmazásra, arról egyéb példákat is hozhatunk. A demokratikus ellenzékből 1988 novemberében megalakuló SZDSZ a nemzeti szuverenitást, az állami függetlenséget és a katonai tömbök nélküli Európa álláspontját képviseli, s a párt programjában nem egyértelműen köteleződik el a Nyugat mellett.7 Kis János pedig egy cikkében még 1989 elején is megemlíti, hogy a magyar társadalom mindezidáig nem emésztette meg a nyugati országok 1956-ban tanúsított „ambivalens” magatartását (Kis 1989: 681). Amolyan kisállami öntudattal azt is megállapítja: Kelet-Közép-Európa sorsát ne a nagyhatalmak döntsék el. „Azt várjuk, hogy olyan világhatalmi helyzetet teremtenek, amelyben Kelet-Európa népei végre maguk dönthetik el, milyen politikai berendezkedésben kívánnak élni." (Kis 1989: 681)

Végül megemlíthetjük, hogy 1989-ben az ellenzék a rendezett átmenet híve, s ehhez részletes külpolitikai javaslatokat is társít. Felhívja például a figyelmet arra, hogy a Varsói Szerződésből történő idő előtti kiugrások félelemmel töltenék el a nyugati országokat, különösen az angolszász hatalmakat és Franciaországot, amelyek attól tartanak, hogy „a Varsói Szerződés kezdődő bomlása a semlegesség választására ösztönözné az NSZK-t, s így a NATO gyors és teljes széteséséhez ve-

\footnotetext{
${ }^{7}$ A Szabad Demokraták Szövetségének elvi nyilatkozata. BÖK, III. kötet, 655.
} 


\section{KÖZELKÉP - Tanulmányok}

zetne". (Kis 1989: 685) Ebből a megfontolásból jut arra a következtetésre Kis János, hogy - bár a Varsói Szerződés távlati megszűnése kívánatos - pillanatnyilag a két tömb együttes és kiegyensúlyozott leépítésére törekedni.

A magyar demokratikus ellenzék rendszerváltás előtti története azt igazolja, hogy az európaiság, a Nyugathoz való csatlakozás csak áttételeken keresztül érvényesül, s az ellenzék programjai sok - a helyzetből fakadó - kompromisszumot is tartalmaznak. Ugyanakkor azt is látjuk, hogy a programok annyiban is igazodnak a korszellemhez, hogy fontosnak és megvalósítandónak tekintik a nemzeti szuverenitást. Ilyen jellegú programot a rendszerváltás után az SZDSZ már nemigen képviselt, s ahogy haladunk előre az időben, a párt egyre inkább a „tiszta” nyugatos mintakövetés pártjává lett.

\section{A mintakövető európaiságtól a mintaformáló európaiság felé}

\section{A FIDESZ MINT A MINTAKÖVETÉS KRITIKUSA ÉS ORBÁN VIKTOR MINT A MINTAFORMÁLÁS IDEOLÓGUSA}

Fentebbi saját elit-fogalmam negyedik pontjaként említettem, hogy a külpolitikai tematikát erőforrásként felhasználó elitek köréből kiemelkedik kettő, amely képes volt rendszerváltás-értékű Európa-kép megalapozására. Az elsőt láttuk. A demokratikus ellenzék és az SZDSZ olyan intellektuális potenciált halmozott fel, amely 1990 és 1994 közöttellenzékből is meghatározta az Európáról való gondolkodás kereteit és normáit. Ahhoz, hogy a Fidesz valaha is kormányzati szerepbe kerüljön, és ha oda kerül, elkerülje az MDF sorsát, ${ }^{8}$ szüksége volt arra, hogy európaiság tekintetében versenyképes alternatív koncepciót dolgozzon ki.

(A Fidesz szocializációs háttere és a késő Kádár-kori elitek). De nem csak amiatt szorult arra a Fidesz, hogy Európáról saját képe legyen, mert ez volt nagy párttá növekedése egyik feltétele. ${ }^{9}$ Szerepet játszott egy generációs motívum is. Bár a szervezet 1988-ban alakult, s tagjai (például a szakkollégiumi mozgalom révén) jelen voltak a '80-as évek második nyilvánosságában, mégsem kapcsolódott szervesen a késő Kádár-kori elitekhez. Stumpf István egy tanulmányában fel is vázolja, hogy itt egy új generáció jelenik meg, amely a korábbiakkal szemben áll (Stumpf 1990, Róna-Tas 1991). A korszakban egyébként is nagy a „generációs probléma”, s a Kádár-rendszer bukásának okát sokan abban vélik megtalálni, hogy az elöregedett régi generáció mögött feltorlódtak, és nem jutottak szerephez az újak. vel is.

${ }^{8}$ Az MDF 1994-ben nagy vereséget szenvedett a választáson és ugyanez történt koalíciós partnerei-

${ }^{9}$ A másik feltétel belpolitikai volt: társadalmi beágyazódásának megteremtése (Tellér 1996). 


\section{KÖZELKÉP - Tanulmányok}

A Fidesz népszerűségét mindenesetre a kezdeti években generációs lendülete, nem pedig nyugatos elkötelezettsége vagy liberalizmusa adta. Elég pontos a korabeli Fidesz-tag és gazdaságpolitikai szakértő, Urbán László önmagukról írott jellemzése: „A Fidesz generációja nem igazán tud lelkesedni semmilyen politikai ideológiáért, sem a nemzet nagysága, sem magasztos liberális elvek nem számíthatnak kritikátlan azonosulásra és követőkészségre". Bármennyire is az az uralkodó vélemény ekkor, hogy a Fidesz liberális párt, kapcsolata kezdettől nem felhőtlen a másik liberális párttal, az SZDSZ-szel. Laki Mihály (SZDSZ-körüli közgazdász) már 1991 februárjában írja: „a véleményformáló értelmiség jelentős csoportjai elfordultak az utóbbi hónapokban a párttól”. A Fideszről talán az első könyvet író Wéber Attila úgy véli: a párt 1992 végétől kezdődő népszerűségvesztésének oka, hogy szembekerült a status quo elitjének koalíciójával (Wéber 1996: 60).

Itt tehát korán szembe ütközünk egy, a későbbiek szempontjából meghatározó szociológiai problémával. Miközben Magyarországon jobboldali koalíció kormányoz, az ellenzéki térfélen - pártpolitikai értelemben - közeledni kezdenek egymáshoz azoknak az eliteknek utódai, amelyek a '80-as évek „diszkurzív diktatúrájának” képviselői voltak, ${ }^{10} \mathrm{~s}$ ebben a körben nincs benne a Fidesz. Innét indul a Fidesznek, mint alternatív elitnek az igazi története. 1994-ig ugyanis a Fidesz amolyan kiegészítő liberális párt, melynek megvan ugyan a saját véleménye, de az SZDSZ vezető körei részéről kezdettől fogva folyamatos kritikák érik. Bauer Tamás például már egy 1990-es írásában azt a megállapítást teszi, hogy a Fidesz programjában kevéssé (kiemelés az eredetiben) vannak kidolgozva a politikai rendszerre vonatkozó pontok. Ugyanebben az írásában azt is mondja Bauer, hogy az SZDSZ és a Fidesz kapcsolata nem természetes szövetségen alapul. Anélkül, hogy a két párt egymáshoz való viszonyának történetébe belemennénk, bizonyosnak látszik, hogy számos ok miatt a két liberális párt már az első ciklusban jelentősen eltávolodik egymástól. És ebben nagy szerepe van a generációs tényezőnek, illetve annak, amit a mintakövető és a mintaformáló Európa-kép közötti ellentétnek nevezek.

(A mintaformáló stratégia néhány eleme a pártprogramokban). A Fidesz egészen korai programjaiban (1988-89) is vannak már a másik liberális (és a szocialista) pártétól eltérő elemek. A Fidesz még „legliberálisabb” korában (tehát alakulásakor) sem tesz például olyan kijelentéseket, hogy létezik „önkéntes szuverenitáskorlátozás”. Igaz, nem is „teljes” szuverenitásról beszél, amikor kijelenti: „Állami külpolitikánk egyik célkitűzése kell legyen, hogy visszanyerjük szuverenitásunknak azt a mértékét, amely sokoldalú, kölcsönös függőségeken alapuló világban lehetővé teszi számunkra, hogy egyenrangú tagjaivá váljunk az európai népek közösségének". Ekkor még a Fideszre is többé-kevésbé jellemző a mintakövetés. De 1994 és 1998 kö-

${ }^{10}$ Ismételten visszautalok, hogy magam nevezem könyvemben diszkurzív diktatúrának az 1980-as évtizedet. 


\section{KÖZELKÉP - Tanulmányok}

zött a párt már másképpen teszi ki a hangsúlyokat. Ebben a korszakban kezdődik az alternatívakeresés a baloldali-liberális koalíció külpolitikájával és a mögötte meghúzódó Európa-felfogással szemben.

Az 1994-es Úton Európába című program például már nem egy stabil EU-ról ír. Ha pedig nem stabil, akkor a követés sem lehet szolgai, ezért az integrációra készülve alternatívákban kell gondolkodni. A hazai pártok mezőnyében egyedülálló módon a Fidesz konkrét reformjavaslatokkal él 1994-ben. Ilyen például az ENSZ reformja, az EU döntéshozatali rendszerének reformja, az Európai Parlament hatáskörének bővítése, a közösség ügyeinek nagyobb nyilvánossága vagy annak szorgalmazása, hogy a polgárokat illető döntések hozzájuk közel szülessenek meg.

Az 1996-os A Polgári Magyarországért című program újdonsága, hogy ebben a Fidesz már konfrontálódik a kormányoldal Nyugat-felfogásával. Hiszen „Európát, az európai mintákat, az állítólagos elvárásokat a kormánypolitika szinte minden helyzetben aduként igyekszik kijátszani. Érdekeinek megfelelően kiragad egyegy intézményt, szabályozót, intézkedést, melyet egy-egy országban alkalmaztak, általános európai normának tüntetve fel azt”. Egyfelől a Fidesz a Nyugatot mint ezer éves keresztény szellemiségű kultúrát értelmezi, amelyre ráépültek az Európai Uniót alkotó országok. ${ }^{11}$ Viszont az Európai Unió 1996-ban nem képes biztonságot garantálni tagjai számára, mégpedig azért, mert „az Európai Unió a maastrichti csúcsértekezlet óta belső válsággal küszködik, és egyre inkább nyilvánvaló, hogy amíg gondjain nem tud a maga számára megnyugtató módon úrrá lenni, a bővítés kérdését csak vonakodva kezeli, és ezt a folyamatot nem, vagy csak igen kismértékben igyekszik előmozdítani." A program hangsúlyosan szól a „brüsszeli nyomásról”, és ennek tükrében azt is megfogalmazza, hogy „majdani tárgyalási magatartásunk tehát nem a mindenáron való alkalmazkodás, mindenfajta követelés és ajánlás elfogadása, hanem a különböző területeken jelentkező magyar érdekek következetes és változó körülményeknek megfelelő állandóan módosuló megfogalmazása és képviselete”. A program azzal fejeződik be, hogy „Magyarország nem jár el helyesen, ha a csatlakozást megelőzően túlzott lojalitástól vezetve szolgai módon lemásolja az EU szabályzatát."

1996 és 2010 között még számos alkalommal fogalmazza meg a Fidesz a Nyugattal kapcsolatos kritikáját, illetve mond véleményt a hivatalban lévő baloldali liberális kormányok EU-politikájáról. A 2007-es Jövő́nk című vitairatban már maga az alkalmazkodás fogalma is kritika tárgyává lesz, hiszen azt olvashatjuk, hogy az már szinte kényszerré vált, miközben az ország észre sem veszi, mihez alkalmazkodik. A Fidesz mindazonáltal nyugatos pártnak tekinti önmagát, s megállapítja: a polgárosodás nyugatról jön. De a vitairat szerzői megfogalmazzák kételyeiket is: „vajon nem délibábot kergetünk-e, nem arról van-e szó, hogy minél gyorsabban akarunk nyuga-

${ }^{11}$ Ehhez a korai megállapításhoz képest érdekes, hogy sokak számára húsz évvel később is meglepetést okoz a Fidesz keresztény alapállása. 


\section{KÖZELKÉP - Tanulmányok}

tivá válni, annál nagyobb lesz a lemaradás". S azt is megállapítják, a lemaradás nem gazdasági okokból következett be: „Bármennyire is gazdasági kérdésről van szó, a válasz a politikai körülményekben keresendő”. Ez pedig a „szocializmus csapdája”.

(A miniszterelnöki szónoklatok Európa-képe). 2007-ben, A Jövőnk program kiadásának évében, Tusnádfürdőn, Orbán Viktor beszédében még egyértelműbben kerül fókuszba az Európa-tematika, és ezzel az évvel kezdődik a nagyívű, Európa-centrikus beszédek sora. Ez az az év, amikor már az őszödi beszéd után vagyunk, a kormánykoalíció „béna kacsa” állapotban van, és Orbán Viktor már ekkor jó eséllyel pályázhat arra, hogy a jövő vezető politikusává váljék. Az ettől az évtől induló beszédekben egy önbizalomtól duzzadó, kormányzásra és Európa átformálására készülő politikus képe bukkan elő. Ez utóbbit talán a 2000-es évek közepe kapcsán talán még korai kijelenteni, de annyiban mégsem, hogy ettől kezdődően Orbán a magyar és az európai baloldal megítélését elválaszthatatlannak tartja egymástól. „Európában új politikai és szellemi mozgalom kezdődött” - mondja 2007-ben -, melynek lényege az elmúlt évtized nyomán kialakult politikai és gazdasági keretek újragondolása. A válságba kerülo korszakot az 1968-as „kulturális ellenforradalomtól” datálja, amely egyoldalúan felértékelte az egyéni szabadságot más szabadságok (például a közösségi szabadságok) rovására. Orbán egy több évtizedes korszellem végéről is beszél, amelynek eredményeképpen lényegében mindent újra kell gondolni. Noha homályban hagyja az általa jelzett „új szellemi mozgalom” nemzetközi bizonyítékait, a pártpolitika világára egyértelmű kívánalmakat fogalmaz meg: az új helyzetben „új típusú pártokra van szükség”, s „egyetlen politikai párt sem maradhat többé olyan Európában, mint amilyen eddig volt". A jobboldal - véli - e tekintetben jóval a baloldal előtt jár; a baloldal - legalábbis Magyarországon - „provinciális, kisszerű és dogmatikus”.

Innentől kezdve pedig Európa kapcsán évről évre újabb és újabb dimenziók kerülnek elő, és a Fidesz elnöke számára már nem az a kérdés, hogyan kövessük a Nyugatot, és hogyan alkalmazkodjunk hozzá, hanem az, hogy ha a Fidesz helyzetbe kerül, hogyan kell Európát átalakítani. 2008-ban - ugyancsak Tusnádfürdőn - Orbán Viktor a válság meglehetősen apokaliptikus olvasatát adja: „még nem értjük pontosan, hogy csak a Nyugat, a modern Nyugat korszakának végéhez érkeztünk-e, vagy az egész emberiség kerül egy új dimenzióba, egy új térfogatba". 2009-es beszédében pedig azt mondja: megbukott a Nyugaton kitalált és eddig alkalmazott gazdasági és politikai „mitológia” (az általa korlátozatlannak vélt piac), s a feladat nem kisebb, mint hogy „az egész európai civilizációt kell megújítanunk”.

A 2008-ban nyitva hagyott kérdésére (a Nyugat vagy az egész emberiség van-e válságban?) 2010-ben Orbán Viktor, már újra miniszterelnökként azt mondja: „a nyugati típusú kapitalizmus” van válságban. S ez a válság „nem átmeneti pénzügyi zavar", hanem azé a rendszeré, amelyben Európa az elmúlt száz-százötven évét élte. A 2011-es tusnádfürdői beszédben újra a korszakváltás fogalma áll a középpontban, de itt már „a régi világ helyén épülő új világról” esik szó. Vitatkozik azokkal, akik szerint a kapitalizmus egyszerű megújulásáról van szó: „nem új fejlődési szakaszba 


\section{KÖZELKÉP - Tanulmányok}

lépünk, nem áttörünk valahonnan valahova, hanem összeomlás következik be és onnan indul meg egy újrakezdés”. Mivel pedig az „összeomlás” lényegében elkerülhetetlen, a Nyugattal kapcsolatos hagyományos mintakövetés is értelmét veszíti. „Ma az a helyzet, hogy akiket követhetnénk, azoknak a fáklyája kialudt". Ezért aztán - s ez újabb következtetés - a létrejövő új gazdasági korszak súlypontja nem Nyugat-, hanem Kelet-Közép-Európában lesz. 2012-es beszédében pedig mindehhez hozzáteszi: a mai nyugati válság oka, hogy Európa ma is a 2. világháború árnyékában él s fél azoktól az erőktől (nemzetektől), amelyek a második világháborút okozták. Mindenekelőtt az a probléma, hogy a Nyugat szerint a 20. század felelősei a kelet-közép-európai kis országok, amelyeket a Nyugat azóta is lenéz. A beszéd elkanyarodik még a mai európai „felelőtlenség” felé is, amelynek fo letéteményeseként a „személytelen" brüsszeli bürokráciát nevezi meg. Mindazonáltal Nyugat-Európát nem szabad megtagadni, mert Magyarország a Nyugat sikerében érdekelt. Ugyanakkor „semmi értelme a Nyugatot másolni, hanem a szabadság szellemének jegyében a saját gazdasági rendszerünket kell fölépíteni".

A nélkül, hogy végigelemeznénk a 2013 utáni beszédeket, megállapíthatjuk: a miniszterelnök amolyan egyszemélyes Európakép-gyártóként, agytrösztöket és folyóirat-elemzéseket is helyettesítő módon foglalkozik Európa kérdéseivel és teszi egyértelművé: az ő Nyugat-felfogásában azért van szükség mintaformálásra, mert a minta nyugat-európai működtetői önmagukban nem boldogulnak a kihívásokkal.

Ugyanakkor meg is lepődhetünk, mert bizonyos értelemben visszajutottunk oda, amikor az MSZMP vezetése az 1970-es években a kapitalizmus „mélyülő válságáról” és a szocializmus „világméretű és szükségszerű győzelméről” beszélt. A miniszterelnöki beszédekben a frazeológia más, de a hasonló a logika: a mintakövetés azért nem megoldás, mert nincs mit követni.

\section{Európa-értelmezések váltógazdasága -magyarázatok}

A fentiekben - leíró szinten - láthattuk, hogy hogyan jött létre a mintakövető elit-felfogás, és mellette, vele rivalizálva hogyan jelent meg a Fidesz által képviselt mintaformáló attitűd. Most az lesz a feladat, hogy magyarázattal is szolgáljak erre a változásra. Először szeretném végig venni az ún. objektív tényezőket, értve ez alatt azokat a külső függőségi és geopolitikai viszonyokat, amelyek az 1980-as években hozzájárultak egy mintakövető, míg a Fidesz kormányzásai idején egy mintaformáló Európa-kép kiformálódásához. Másodszor pedig áttekintem az ún. szubjektív feltételeket, legfőképpen a mintakövetőnél jóval kevésbé ismert mintaformáló motiváció történeti gyökereit. 


\section{KÖZELKÉP - Tanulmányok}

\section{AZ OBJEKTÍV DIMENZIÓ: A KÜLSŐ FÜGGŐSÉG-FAKTOR}

\section{ÉS A GEOPOLITIKA MINT A NYUGATOS ELIT-MAGATARTÁS MEGHATÁROZÓJA}

(A késő Kádár korszak függőség-változásai és a geopolitika átmeneti vége). Nyilvánvaló, hogy a Kádár-rendszert nem kezelhetjük egységes egészként, hanem szakaszokra kell bontanunk. Utólag nézve könnyen juthatunk arra a következtetésre, hogy a rendszer belső fejlődése a Nyugat-elleneségtől a nyugatosság felé tart(Böröcz 1993). A rendszer múködésének leghosszabb szakasza (1956 és 1977 között) a szovjet függés korszaka. Ebben a periódusban a külső erőteret a Szovjetunió jelenti, a gazdasági, társadalmi és politikai fejlődés szovjet mintát követ, és a politikai vezetésnek (melynek más elitcsoportok nem riválisai ebben az időszakban) ugyanaz a célja, mint más kelet-közép-európai országokban: Nyugat-Európa túlszárnyalása és a szocializmus magasabbrendűségének bizonyítása. Ebben a megközelítésben két különálló világrendszer (egy szocialista és egy kapitalista) létezik, és a korabeli magyar pártvezetők természetesen a szocialistát tartják a béke védelmezőjének a kapitalista országokkal szemben, melyek folyamatosan veszélyeztetik a békét. Fontos kiemelni, hogy mivel két egymástól hermetikusan elzárt világrendszerként képzelik el Nyugat- és Kelet egymás mellett élését, nem is nagyon használhatjuk itt sem a mintakövetés, sem a mintaformálás fogalmakat.

A második (1978 és 1988 között) kettős függés korszaka, amikor új konstelláció alakul ki a hatalom és a hatalmon kívüli tényezők szintjén. Először is fokozatosan módosul a Nyugat hivatalos megítélése: az MSZMP vezetőinek egy része és a körülötte lévő pártelit kezdi felülvizsgálni korábbi felfogását a két különálló világrendszerről, és számos olyan megnyilatkozás lát napvilágot, miszerint immár csak egyetlen világrendszer van, és ahhoz Magyarországnak kell alkalmazkodnia (nem az fog a szocialista világrendszerhez). Másodszor, maga a Nyugatról való gondolkodás új értelmet nyer az által, hogy a pártvezetésen és a párteliten túl egyéb elitcsoportok is megjelennek, amelyek néhány tekintetben „felcsatlakoznak” a hivatalos nézetekhez, de számos téren eltérő módon kezdik értelmezni Nyugat-Európát, illetve a Nyugat és Kelet kapcsolatát, megtörve az MSZMP addig töretlen Nyugat-értelmezési monopóliumát. Ehhez még az tartozik, hogy a világrendszerek közeledése korában nyer értelmet a mintaformálás is. A 70-es évek végén, a 80-as évek elején a hivatalos pártvezetés még megpróbálkozik azzal, hogy - a szocializmus fölényére hivatkozva - formálni próbálja a Nyugatot. Például a béketeremtésen keresztül. ${ }^{12}$

Végül a harmadik (a Kádár-rendszer utolsó éveiben) a nyugati függés korszaka, amikor a korábbi „vegyes függőségből” megtörténik az átmenet az egyértelmű nyugatos rendszerváltásba. Ennek a szakasznak az a lényege, hogy a pártvezetés már

${ }^{12}$ Különösen érdekes ezt felidézni, hiszen napjainkban az 1945 utáni liberális világrendet szokás a béke garanciájaként emlegetni. A néhai pártvezetés dokumentumaiban számos megállapítással találkozhatunk a Nyugat átformálásával kapcsolatban. 


\section{KÖZELKÉP - Tanulmányok}

nem tud ellenállni a változásoknak, $\mathrm{s}$ a demokrácia megteremtése válik elsőrendû feladattá. Ez az a korszak, amikor az egyes hatalmon kívüli elitcsoportokból megalakulnak a pártok, és kialakul a sztenderd Nyugat-kép, amely az átmenet éveiben és utána jó ideig irányadó. Megszületik a mintakövető nyugatosság, mely tehát a létező nyugat-európai minták mind teljesebb átültetését látja elsőrendű feladatának. Itt tehát a korai Kádár-korszak mintaformáló attitûdjét már nem érhetjük tetten.

Egyértelmű, hogy a kései Kádár-korszakban nincs alternatívája a mintakövetésnek, mert a Magyarországnak a szovjetrendszerből való kiszabadulását a fejlett nyugati országok segítségével sikerülhet csak elérni. Az átmenet előestéjén egyértelműnek látszik a képlet, amit Francis Fukuyama: A történelem vége? címú híres tanulmányában liberális világforradalomként ír le (Fukuyama, 1990). Csakhogy érdemes Fukuyama tanulmányát egy kicsit mélyebben is megnéznünk. A magabiztos frazeológia mögött ugyanis a liberális világforradalom törékenysége sejlik fel.

Az még magabiztos kijelentés, hogy „tökéletesen kimerült a nyugati liberális demokráciával szembeni összes alternatíva" (Fukuyama 1990: 16) és hogy véget ért a „világtörténelem”. De ha nincsenek is alternatívái a liberális demokráciának, mégis vannak országok, amelyek nem válnak mégsem liberálissá. Japánról, Kínáról és a Szovjetunióról (ekkor még ez utóbbi létezik) ír a szerző, s megállapítja róluk: befolyásuk jelentős, bár egyik sem képes/tud hatékony eszmei-gondolati alternatívát állítani a liberális demokrácia univerzális normájával szemben. Kínáról például ezt rögzíti: ma már nem lép fel „a földkerekség liberalizmusellenes erőinek zászlóvivőjeként" (Fukuyama 1990: 24). Nem azt mondja tehát, hogy akár Kína, akár a Szovjetunió átalakulása szükséges lenne a liberális világforradalom győzelméhez. Csupán annyi kell, hogy „az államok feladják ideológiai igényeiket (kiemelés - Cs. E.), miszerint az emberi társadalom fejlődésének más jellegű, magasabb rendű formáit képviselik" (Fukuyama 1990: 26). A Szovjetunió kapcsán pedig azt állapítja meg, hogy az sem nem liberális sem nem demokratikus ország. De „a történelem végén korántsem szükséges, hogy minden társadalom sikeresen átváltozzon liberális társadalommá; pusztán arról van szó, hogy az államok feladják ideológiai igényüket, miszerint az emberi társadalom fejlődésének más jellegü, magasabb rendű formáit képviselik" (Fukuyama 1990: 26). S tovább: „A jövőre vonatkozó tulajdonképpeni kérdés az, hogy mennyire fogadják be a szovjet elitek(kiemelés - Cs. E.) a homogén egyetemes állam tudatát, melyet a Hitler utáni Európa képvisel" (Fukuyama 1990:30). S ha az olvasó még ennél is egyértelmúbb jelzést vár a szerzőtől, azt is megkapja, merthogy Fukuyama szerint a Gorbacsov mögötti elitek eljutottak(kiemelés - Cs. E.) a „történelem vége" állapot elfogadásáig (Fukuyama 1990).

Ezek a megfogalmazások egy bizonytalan kimenetelü, az ellenérdekelt felek mozgásától nagymértékben terhelt jövőről szólnak. Francis Fukuyama javára írható, hogy számol a liberális demokráciák ellenfeleivel, sőt határozottan elismeri a nem liberális demokráciák további jelenlétét, de nem tud válaszolni arra a kérdésre, hogy 


\section{KÖZELKÉP - Tanulmányok}

mi van, ha a liberális demokráciák létrejöttét pillanatnyilag nem blokkoló rezsimek később megváltoztatják álláspontjukat és határozottabb ellenállást tanúsítanak a liberális demokráciákkal szemben. Ezt a dilemmát nekünk most csak abból a szempontból kell felvetnünk, hogy lássuk: a mintakövető nyugatosság egy megfelelő és támogató külső klímában (a Szovjetunió passzív vereségének légkörében) jött létre, ám ebben a helyzetben kezdettől benne volt (mint azt Fukuyama sorai feltárják előttünk) a bármikori visszarendeződés veszélye. ${ }^{13} \mathrm{~S}$ valóban így is történik majd: nem csak a történelem, hanem a geopolitikai is visszatér majd a 2000-es években, s ennek, ha nem is közvetlenül, de áttételesen hatása lesz arra, hogy a rendszerváltáskor egyedülinek hitt nyugatos mintakövetés mellett megjelenhet egy másfajta (éppen a bizonytalanságból építkező) Európa-attitűd.

(Az 1989-90-ben létrejövő demokratikus rendszer belső szakaszolása és a változások hatása a mintakövetố-mintaformáló vitára). Amint a Kádár-rendszert, úgy a demokrácia korát sem tekintem egységesnek, hanem szakaszokra bontom, két szempont mentén. Az egyik a külső függés intenzitása és iránya, a másik a demokrácia állapota. Az első szakaszban, az 1990 utáni években a legkisebb a külső függés érzete. A szovjet függés végérvényesen a múlté, és fel sem merül, hogy a nyugati függésnek negatív hatása lenne. Az ország természetes módon, a nemzeti függetlenség visszanyeréseként éli meg a demokratizálódást. Ez az az időszak, amikor a demokratikus elitek végérvényesen győzelmet aratnak a diktatúra erői felett, és létrejön a „tiszta” demokrácia, amit a demokrácia „jóságába” vetett hit múködtet. Ennek az időszaknak egy kiegyensúlyozott Európa-kép felel meg: Európa segített nekünk a diktatúra leépítésében. Ez nagyjából az a korszak, amikor létrejönnek a pártok, megtörténik az első választás és világossá válik, hogy a diktatúra nem tud feltámadni. A 90-es évek nagy része e tekintetben - mint már utaltam rá - egyértelmú: a geopolitika (úgy tűnik) megszűnik rendszerformáló tényező lenni. Korábbi kifejezéseinket használva: Magyarország nyugati függésbenvan. Ennek egyértelmű példája, hogy az ország 1999-ben csatlakozik a NATO-hoz és felkészül az európai unióba való belépésre. A politikában ez azt jelenti, hogy a külpolitika lényegében konszenzusos terület, habár sok ellenzéki bírálat éri az Antall-, majd a Horn-kormányt. ${ }^{14}$ De a mindent meghatározó fő tényező, hogy (a Fukuyama-tételnek megfelelően) az orosz elitek lojálisak a demokrácia és az Egyesült Államok ügyének. Hogy ez mennyire így van, s aJelcin-féle orosz vezetés és az Egyesült Államok vezetése között milyen szívélyes a kapcsolat, arról nem más, mint Soros György tájékoztat minket. ${ }^{15}$

${ }^{13}$ 2015-ös tanulmányában Levitsky és Way azt írja, hogy voltaképp nem is történt demokratizálódás Kelet-Közép-Európa nagy részében, hanem csak az autoriter államhatalom átmeneti elgyengülése (Levitsky - Way 2015).

${ }^{14}$ Lásd a külpolitikai konszenzusláncról: Csizmadia 1997.

${ }^{15}$ Soros György részletesen szól arról, hogy milyen szerepet játszott az orosz kormány politikájának alakításában. 


\section{KÖZELKÉP - Tanulmányok}

A második korszakban (az 1990-es évek közepétől) egyrészt a geopolitika újra kezd szerepet játszani, s éppen a Fukuyama által is jelzett kritikus pontokon. A Jelcin-rendszernek vége lesz és a 2000-es évek elejétől a korai putyinizmus következik. Ekkor még nem változik meg alapjaiban a demokratizálás által kialakult szerkezet, de Fared Zakaria a 90-es évek második felében jelzi, hogy a liberális demokráciák világméretű győzelme nem sikerült, merthogy illiberális rendszerek is létrejöttek (Zakaria 1997). Magyarországon ez a korszakmég nem az illiberális, hanem a liberális demokrácia kialakulásának kora, hiszen - mint írtam - az átmenet első éveiben egy „tiszta” (jelzőnélküli) demokrácia jött létre. Ebben a korszakban a legerősebb az SZDSZ, amely az 54\%-os MSZP-kormányban 18\%-os arányban vesz részt. És ez a korszak, amikor megfogalmazódik a Fidesz kritikája a kormányzati elit Nyugat-felfogásával szemben.

Végül a harmadik nagy periódus, amikor Magyarországon „ismét” a hivatalos politika rangjára emelkedik a mintaformáló Nyugat-kép. A korábbiakban láttuk, hogy a néhai MSZMP az 1970-es években próbálkozott a mintaformálással, ám ezzel a 80as évek elejétől felhagyott. Természetesen nem azt állítom, hogy a Fidesz az MSZMP e korai felfogásának örököse, azt azonban igen, hogy a geopolitikai körülmények változása ismét előidézi azt a helyzetet, amikor egy uralmi helyzetben lévő erő átértékeli az azt megelőző Európa-felfogást, és attól eltérő alapállásra helyezkedik. Ez már érlelődik a Fidesz első kormányzása (1998-2002) alatt, de teljes valójában 2010 után mutatkozik meg. Ekkor már a demokrácia értelmezésében is új szakasz kezdődik, hiszen a második periódusban meghonosodó liberális demokrácia-értelmezést az illiberálisállam és demokrácia eszméje váltja fel. ${ }^{16}$ Mindehhez hozzá kell tenni még azt is, hogy a politika csúcsán bekövetkező változás támaszkodik arra a fordulatra, amely a rendszerváltás jelen-centrikus szemléletéhez képest is egy jóval történetibb nézőpontot rehabilitál. De amint az átmenetnek is volt politikatudományi alapozása (és ez a tranzitológia), úgy ebben az időszakban a politikában megjelenő történelmi látásmódnak is van politikatudományi megfelelője, s ez az új historicizmus. ${ }^{17} 2007-b e n$ megjelenik Robert Kagannak a történelem visszatéréséről szóló könyve (Kagan 2007), amely pontosan ugyanúgy szimbolikusanis kifejez egy életérzés-változást, mint ahogy Fukuyama 1990-es cikke, majd könyve is (Fukuyama 1994). És ahogy a „történelem vége” teóriából Magyarországon a bal- és a liberális oldal profitált, úgy a „történelem visszatérésének” haszonélvezője a jobboldal lesz. Megállapíthatjuk tehát, hogy mind az 1980-as évek elitje, mind a Fidesz-elit egy-egy történelmi (objektív) változásnak köszönheti felemelkedését. Fontos azonban hangsúlyozni: ez nem direkt determináció. Ahogy a baloldali és liberális elit-formálódás-

${ }^{16}$ A ritka írásos kifejtések közül lásd: Tellér 2014.

${ }^{17}$ Grzegorz Ekiert az átmenet utáni politikatudomány három fontos irányzata egyikeként említi a „új historicizmust" (Ekiert 2015). 


\section{KÖZELKÉP - Tanulmányok}

hoz is kellett az elitek elhatározása, előélete, kreativitása, úgy a magyar jobboldal is azért tudott felemelkedni, mert a szubjektív hátteret is megteremtette ehhez.

\section{SZUBJEKTÍV DIMENZIÓ: A MINTAFORMÁLÁS \\ MINT A MAGYAR JOBBOLDAL LAPPANGÓ TÖRTÉNELMI ÖRÖKSÉGE}

Az objektív tényezők mellett legalább ilyen fontosak a szubjektívek. Ezek sorában pedig azok, hogy honnan merítik értékeiket az elitek. Az 1980-as évek ellenzéki elitje bár nagyon jelen-centrikusan látta a világot, de nem mulasztotta el jelezni, kikre, milyen elődökre támaszkodik. Az, hogy az ellenzék erősen hangsúlyozta Jászi Oszkárhoz vagy Bibó Istvánhoz füződő viszonyát, egyúttal azt is jelezte, hogy a liberális nyugatosság felépítésében fontos szerepet játszottak azok az elődök, akik a maguk korában szintén a mintakövető gondolkodás képviselői voltak. ${ }^{18}$

Sokkal kevesebbet (majdhogynem semmit) nem tudunk azonban a jobboldal elődválasztásairól. Alig valamit tudunk arról, hogy egy mai jobboldali számára mi és miért fontos a történelemből. Mivel írott programok nincsenek, csak a már említett miniszterelnöki beszédekre hagyatkozhatunk, ha meg akarjuk tudni, mit is jelent valójában a mintaformáló típusú Európa-attitűd. Így hát a Fidesz esetében részben közvetett eljáráshoz kell folyamodnunk, ha a történelmi elődökhöz való viszonyt akarjuk rekonstruálni.

(A mintaformálás mint „rangrejtett” történelmi elit-attitűd). A mintaformálás (mint láttuk) egészen más Európa-felfogás, mint a mintakövetés. A mintakövetés hívei meg vannak győződve arról, hogy Magyarország hátrább tart a fejlődésben, mint a fejlett országok és csökkenteni kívánja a távolságot. A mintaformáló attitűd hívei már a kiindulópontban sem értenek egyet, és azt mondják: Magyarország számos területen nem rosszabb, mint a fejlett országok. Ez az attitűd a Fidesz felnövekedésével párhuzamosan jött elő, de valójában a régebbi történelmi korok (elfelejtett) terméke. Ez utóbbi azonban nem ok arra, hogy ne vegyük észre: a mintaformálás mégiscsak része a magyar eszme- és gondolkodástörténetnek. Ennek igazolására elég elolvasnunk néhány alapvető munkát, amelynek szerzői erről beszélnek. Csak illusztrációként hadd hozzak három példát.

Az első Beksics Gusztávé, aki a dualizmus korának egyik vezető nemzeti liberális ideológusa. Egyik munkájában írja, hogy Európában a régi Magyarország volt az egyetlen, ahol az alkotmány a nemzetben gyökerezik, szemben minden más országgal, ahol a korona hatalmából. Ebből adódóan nálunk „a korona és a nemzet közjogi egysége” valósult meg évszázadokon át (Beksics 1903: 1-4). A második Bajcsy-Zsilinszky Endre, aki a két háború között írott könyvében azt írja: „a Nyugattal szemben a középkori alkotmányos magyar állam nem a királyság intézményéből nőtt ki,

\footnotetext{
${ }^{18}$ Lásd például az ún. Kék Könyvet, az SZDSZ első programját (SZDSZ kiadványa 1989).
} 


\section{KÖZELKÉP - Tanulmányok}

hanem a nemzeti öntudatból és az önkormányzó akaratból”. Majd még azt is hozzáteszi, hogy a középkori magyar alkotmányosság magasabb rendű, mint a nyugati, és „több eredeti lehetőséget” hordoz magában (Bajcsy 1931: 22-24). Végül szóba hozom Makkai Jánost, aki a két háború közötti kormányzó jobboldal egyik originális figurája és parlamenti képviselője. Számára állandó téma, hogy mi a Nyugat, és hogy hogyan kell viszonyulni hozzá. 1941-ben (a legnagyobb magyar születésének 150. évfordulóján) nyolc részes cikksorozatot ír Széchenyi és a mai reformerek címmel. Az egyik cikkben például ezt írja: nem csak a fejlett, hanem a fejletlen országokat is ismerni kell ahhoz, hogy reformálni tudjunk. „A forradalmárok legfőbb hibája ugyanis az - írja -, hogy csak a Nyugatot ismerik, csak a saját országukénál fejlettebb társadalmak életét tanulmányozzák, és aztán az idegenben látottak hatása alatt idehaza elvesztik a realitás iránti érzéküket”. És nem sokkal később: „Magyarországot sose csak a Nyugattal hasonlítsuk össze, hanem a minket környező népekkel is, mert csak akkor fogjuk látni európai szerepünket és népünk valódi rendeltetését." $S$ végül: „Míg a mai reformerek túlnyomórészt abba a hibába esnek, hogy csúcsteljesítmények utánzására akarnak rávenni bennünket, az igazi reformer az idegen országban a fejlődés reális magját veszi észre, $\mathrm{s}$ ahhoz hasonló tevékenység folytatását ajánlja a nemzetnek." (Makkai 1941: n. a.)

Ezekből az idézetekből is kirajzolódik, hogy a magyar politikatörténet különböző korszakaiban mindig voltak elitek, amelyek nem tartották kielégítőnek a mintakövetést, $\mathrm{s}$ a mintakövetéssel éppen az volt a problémájuk, hogy egy ilyen stratégia nem számol a mintaadó országok és Magyarország fejlődésbeli különbségeivel. Hogy ez mennyire létező probléma Makkai kora után is, arra álljon itt a korábban említett Szűcs Jenő híres régióelmélete, amelyben a szerző szintén azzal foglalkozik, hogy a magyar fejlődés nem olyan, mint a nyugati. Szűcs persze nem használja az általam használt mintakövető vagy mintaformáló kategóriákat, s nem mond olyat, hogy a mintakövetéssel önmagában probléma lenne. Ugyanakkor rámutat: az itthon adaptált nyugati minta mindig a nyugatinál sokkal rövidebb idő alatt, sokkal sürítettebben jelent meg. Nyugat-Európában, írja Szűcs, a fejlődés vívmányai „egy több fázisú, időben is mélyen tagolt fejlődésképletben, mintegy fél évezred alatt épültek organikusan egymásra [...] e keletibb sávban, Magyarországon is, tagadhatatlan összevontsággal, alig másfél évszázad folyamán és egymással párhuzamosan vázolódtak fel." (Szűcs 1983: 60) Ez az értékelés eléggé egybeesik egy másik, Makkai korában élő szerzőével, Prohászka Lajoséval, aki azt állapítja meg, hogy a magyar nem ismeri az organikus fejlődést: „fejlődése mindig lökésszerűen, mondhatni erőszakosan, külső tényezők hatására jött létre." (Prohászka 1936: 88) Külön téma lehetne annak elemzése, hogy a magyar társadalom egyszerre vágyik a „nyugalomra” és a „külső hatások” befogadására (Uo. 89). Mindezek arra utalnak, hogy a magyar társadalomnak a külső környezethez való viszonyában régóta jelen van - a mintakö- 


\section{KÖZELKÉP - Tanulmányok}

vető mellett - egy másfajta Európa-szemlélet is, amely persze önmagában is ellentmondásos, ráadásul nehezen is megfogható.

(Elit és cselekvőképesség). Ahogyan a késő Kádár-korszak mintakövető elitje, úgy a mintaformáló elit is a rendszerváltás utáni történelem egy bizonyos pontján jut szerephez. A Fidesz-elit a korai időszakban (1988-1994) részben fiatal még, részben pedig nem tudja pontosan definiálni magát. Érthető, hogy ennek az időszaknak mások a főszereplői, azok, akik az 1980-as évek második felében inspirációt kaptak a tranzitológia elméletétől (Csizmadia 2016, 2017). A tranzitológia bizonyos értelemben felszabadító elmélet volt, hiszen kiutat mutatott a kettős világrendszer fogságából és megadta ehhez a cselekvés esélyét. A késő kádári elitek nem véletlenül voltak olyan termékenyek - egy egyértelműen előre haladó korban, a demokrácia világméretű győzelme és a kapitalizmus szocializmus feletti triumfálása határozta meg lépéseiket.

A 2000-es években egészen más a politikai klíma, és ebben az időszakban azért lesz főszereplő a jobboldali elitből, mert számára a cselekvés épp olyan felszabadító, mint azoké az elődeié, akik a 80-as évek végén és a 90-es évek első felében voltak cselekvő helyzetben. A Fidesz elitje azért bír nagy cselekvési potenciállal, mert az ő számára a demokrácia már a maga ellentmondásosságában jelentkezik, továbbá még egy új elemmel is bővül: nevezetesen az Európai Unióban játszott magyar szereppel. A mintaformálás azért lesz népszerű, és a választók többsége azért igazolja ezt vissza, mert a széleskörű társadalmi tapasztalat nem az, mint a 80-as években (hogy a külső erőtér segít), hanem az, hogy a külső erőtér nem tudta megteremteni azokat a vívmányokat, amelyek benne voltak a demokratizálás programjában. Az elmúlt évtizedek magyar politikájának viszonylagos sikertelensége ily módon előhívja azt az attitűdöt, amely a mindig is jelen volt a magyar politikatörténetben, amikor a magyar politikai elit nem a külső környezettől várta a megváltást. Ma a külső környezet az uralkodó elit számára nem a megoldást hozó képét mutatja, hanem azt, amely csökkenti a megoldás esélyét. A mintaformáló politikai ideológia ennek a percepciónak a következménye.

\section{Összegzés}

Ezt a tanulmányt azzal kezdtem, hogy vajon jogos-e manapság európaiság és Európa-ellenesség szembeállítása. A fentiekben a mellett érveltem, hogy inkább nem, mint igen. Úgy ítéltem meg, hogy e dichotómia helyett inkább beszélhetünk az európaiság két válfajáról: mintakövetésről és mintaformálásról.

Fontosnak tekintettem bemutatni mindkettő keletkezéstörténetét, illetve kapcsolódását makro- és mikropolitikai motívumokhoz. Ennek keretében bemutattam, hogy miért volt adekvát az 1980-as években a mintakövető álláspont megjelenése. 


\section{KÖZELKÉP - Tanulmányok}

A dolgozat későbbi részében pedig elmondtam, miért jelent meg a mintakövető mellett, mintegy annak kihívójaként a mintaformáló Európa-attitűd a jobboldalon.

Az írás voltaképp azt szeretné nyomatékosítani, hogy a magyar politikatörténet adhat nekünk segítséget az elmúlt harminc évben bekövetkezett fordulat megértéséhez. Ezt még azoknak is érdemes megfontolniuk, akik a Fidesz Európa-politikáját (nevezzük azt mintaformálónak vagy akármi másnak) minden ízében elvetik. Én nem elvetem, hanem csak jobban akarom érteni, s úgy hiszem, talán jobban is értem. A magyar politikatörténetben mélyen benne rejlik az a réteg, amelyet az elmúlt évtizedben a Fidesz előhozott belőle. Ezzel a réteggel pedig akkor is számolnunk kell, ha taszítónak találjuk és elvetjük.

Jó lenne persze, ha elintézhetnénk a dolgot annyival, hogy a történelem „szokásos" menetéről van szó, amit Samuel Huntington demokratikus hullámok és visszafordulások váltakozásaként írt le (Huntington 1991, Lijphart 2000). Nyilván sokan vannak, akik a mintaformáló európaiságban nem látnak mást, mint egy újabb visszafordulást, amit bizonyára követni fog előbb-utóbb egy erőteljes redemokratizálódás. Meglehet, azoknak van igazuk, akik így látják. De csak ismételni tudom: a nyugatosságnak az a válfaja, amely az 1980-as évek közepétől egyre erőteljesebben kialakult, csak az egyik lehetséges opció. Ameddig ugyanis Magyarország külső mintához szabja a politikáját (és valószínűleg ez mindig így marad), addig újra és újra megjelenik majd a másik viszonyulásmód is, nevezzük azt mintaformálónak vagy éppen euroszkeptikusnak. A mintához való viszony kialakítása ezért mindig kihívást jelent az eliteknek, s ezt a kihívást ők arra használják majd fel, hogy helyzetüket stabilizálják és ellenfeleiknél adekvátabb Nyugat-értelmezést adjanak. S éppen azért, mert a minta maga is változik, sosem számolhatunk azzal, hogy akár egyik, akár másik Európa-stratégia örökbérletet válthat magának.

\section{Irodalom}

Ágh A. (1992): A pártok parlamentesedése Magyarországon (1989-1991). Politikatudományi Szemle, 1.125-140.

Ágh A. (2011): Anticipatory and Adaptive Europaization of Hungary. Kossuth Kiadó, Budapest

Bajcsy-Zsilinszky E. (1931): Nemzeti radikalizmus. Stádium Kiadó, Budapest

Bauer T. (1990): Elmélkedés egy vereségről. Beszélő, július 7., 2. évfolyam, 25. szám, http://beszelo.c3.hu/cikkek/elmelkedes-egy-veresegrol (utolsó letöltés: 2019. 11. 19.)

Beksics G. (1903): Közjogunk és nemzeti törekvésünk. Atheneum, Budapest

Bozóki A. - Hegedűs D. (2017): A kívülről korlátozott hibrid rendszer. Az Orbán-rezsim a rendszertipológia tükrében. Politikatudományi Szemle, 2. 7-34. 


\section{KÖZELKÉP - Tanulmányok}

Böröcz J. (1993): Kettős függőség és a külső kötődések informálissá válása: a magyar eset. Eszmélet, 18-19. szám, 74-88.

Chou, M. (2011): When Democracies Fail. Political Studies Review, 3. 344-356.

Csizmadia E. (1990): Milyen ellenzék legyen Magyarországon? I-II. Kritika, 3. 5-8. és Kritika, 4. 28-31.

Csizmadia E. (1998): A magyar pártok Nyugat-Európa képe. Politikatudományi Szemle, 1. 99-118.

Csizmadia E. (2001a): Diskurzus és diktatúra. A magyar értelmiség vitái Nyugat-Európáról a késő Kádár-rendszerben. Századvég Kiadó, Budapest

Csizmadia E. (2001b): Ösztön és politika. Makkai János és a reformjobboldal a két háború között. Új Mandátum Kiadó, Budapest

Csizmadia E. (2003): A pártok alkalmazkodóképessége és a pártverseny dinamikája. In: A politika és az értelmiség. Századvég Kiadó, Budapest, 99-122.

Csizmadia E. (2016): A tranzitológiának vége, felejtsük el? Az átmenet tervezett intézményeitől a tervezetlen hibridizációig. Politikatudományi Szemle, 2. 135-153.

Csizmadia E. (2017): A magyar politikai fejlődés logikája. Összehasonlítható-e a jelen a múlttal, és ha igen, hogyan? Gondolat Kiadó, Budapest

Ekiert, G. (2015): Three Generations of Research on Post Communist Politics -A Sketch. East European Politics and Societies. 2. 323-337.

Fukuyama, F. (1990): A történelem vége? Világosság, 1-2. 1-25.

Fukuyama, F. (1994): A történelem vége és az utolsó ember. Európa Kiadó, Budapest Greven, M. (1995): Demokratizáció és intézményépítés. Politikatudományi Szemle, 1. 9-20.

Huntington, S. (1991): The Democray's Third Wave. The Journal of Democracy, Spring, 12-34.

Kagan, R. (2008): The Return of History and the End of Dreams. Alfred A. Knopf, Publisher, New York

Kagan, R. (2015): The Weight of Geopolitics. Journal of Democracy, January, 21-31.

Kis J. (1989): Forr a világ. Beszélő, 1989/1., 26. szám, http://beszelo.c3.hu/cikkek/ forr-a-vilag (utolsó letöltés: 2019. 11.19.)

Kiss Zs. P. - Derényi A. (1993): Az utánzás régiója. Világosság, 7. 31-43.

Kovács É. - Tóth I. J. (1992): Ki mit mondott 1990-ben? Politikatudományi Szemle, 1. 99-124.

Krastev, I. (2007):Is East-Central Europe Backsliding? The Strange Death of the Liberal Consensus, October, 56-64. 


\section{KÖZELKÉP - Tanulmányok}

Krastev, I. (2018): Eastern Europe's Illiberal Revolution. The Long Road to Democratic Decline. Foreig Affairs, May-June.

Krekó P. - Enyedi Zs. (2018): Explaining Eastern Europe: Orbán’s Laboratory of Illiberalism. Journal of Democracy, July, 39-51.

Kulcsár K. (1984): A magyar szociológia történetszemlélete. Gondolatok a külső minta jelentőségéről. Valóság, 5 .

Laki M. (1992): Körkérdések a Fideszről. In: Bozóki A. (szerk.): Tiszta Lappal. A Fidesz a magyar politikában 1988-1991. Fidesz Központi Hivatala. 734-737.

Levitsky, S - Way, L. A. (2015): The Myth of Democratic Recession. The Journal of Democracy, January, 45-58.

Lijphart, A. (2000): The Future of Democracy: Reasons for Pessimism, but Also Some Optimism. Scandinavian Political Studies, 3. 265-272.

Makkai J. (1937): Széchenyi és a mai reformerek, II. rész. Esti Újság, szeptember 27.

Mitrovits M. (2019): A lengyel hatás a demokratikus ellenzék tevékenységére, 19801981. Századok, 2. 403-428.

Plattner, M. - Diamond, L. (2007): Is East-Central Europe Backsliding? The Journal of Democracy, October, 5-6.

Prohászka L. (1936): A vándor és a bujdosó. Minerva, Budapest

Róna-Tas Á. (1992): Fidesz - mit tesz? Nemzedékek és pártok. In: Bozóki András (szerk.): Tiszta lappal. A Fidesz a magyar politikában. 1988-1991. Fidesz Központi Hivatala, 608-617.

Soros Gy. (1999): A globális kapitalizmus válsága. Scolar Kiadó, Budapest

Stepan, A. -Skach, C. (1993): Alkotmányos keretek és a demokrácia megszilárdulása Politikatudományi Szemle, 4. 51-71.

Stumpf I. (1992): Fidesz - új generáció és szellemiség a politikában. In: Bozóki A. (szerk.): Tiszta lappal. A Fidesz a magyar politikában. 1988-1991. Fidesz Központi Hivatala. 595-607.

Szűcs J. (1983): Vázlat Európa három régiójáról. Magvető Kiadó, Budapest

Tellér Gy. (1996): A három részmagyarország. Századvég, 1. 52-66.

Tellér Gy. (2014): Született-e Orbán-rendszer 2010 és 2014 között? Nagyvilág. Március, 346-367.

Urbán L. (1992): A Fidesz gazdaságfilozófiája. In: Bozóki A. (szerk.): Tiszta Lappal. A Fidesz a magyar politikában. 1988-1991. Fidesz Központi Hivatala, 618-624.

Wallerstein, I. (1992): The Concept of National Development, 1917-1989: Elegy and Requiem. American Behavioral Scientist. March, 517-529.

Wéber A. (1996): A Fidesz-jelenség. Napvilág Kiadó, Budapest 
www. metszetek.unideb.hu

\section{KÖZELKÉP - Tanulmányok}

Wilkin, P. (2018): The Rise of 'Illiberal' Democracy: The Orbánization of Hungarian Political Culture. Journal of World-System Research, Winter-Spring, 5-42.

Zakaria, F. (1997): The Rise of Illiberal Democracy. Foreign Affairs, November-December. 22-43. 